\title{
Rediscovery and subsequent observations of Kaempfer's Tody-tyrant Hemitriccus kaempferi in Santa Catarina, Brazil, with notes on conservation, life history and plumage
}

\author{
JUAN MAZAR BARNETT, GUY M. KIRWAN, MARK PEARMAN,
} LUCIANO NICOLÁS NAKA and JOE A. TOBIAS

\begin{abstract}
Summary
Previously known from two specimens, Kaempfer's Tody-tyrant Hemitriccus kaempferi is a globally threatened species endemic to the southern Brazil Atlantic Forest. The first field observations of this little-known taxon were made in the 1990s and our data therefore provide the first published information on its natural history, including breeding biology, behaviour and vocalizations, as well as a new locality. As very little information has appeared in the literature concerning the identification of this species, we present notes on its plumage and habits. Remarks concerning the species's conservation prospects and the importance of the remaining forest in the vicinity of the type-locality for other threatened bird species are made.
\end{abstract}

\section{Introduction}

Kaempfer's Tody-tyrant Hemitriccus kaempferi is a poorly known endemic of lowland Atlantic Forest of north-eastern Santa Catarina, Brazil that was not even generally afforded specific status until the work of Fitzpatrick (1976). Prior to the 1990s, the species was wholly unknown in life. Its existence rested solely on the basis of two specimens: the type, collected by Emil Kaempfer at Salto do Piraí, near Joinville, Santa Catarina (Naumburg 1939) on 3 June 1929 (Collar et al. 1992), and the second, only recently recognized, taken by H. F. Berla at Brusque, Santa Catarina in 1950 and retained in the Museu Nacional de Rio de Janeiro (Teixeira et al. 1991). There were no subsequent records until July 1991, when M.P. observed a single individual within $1 \mathrm{~km}$ of the type-locality. Although Collar et al. (1992) and Ridgely and Tudor (1994) announced the rediscovery, and Stattersfield et al. (1998) made passing mention of our observations, full details have never been published.

Since 1995, there have been a number of additional observations at Salto do Piraí and another locality by the authors and John Wall. These have provided new data concerning the species's life history, nesting ecology and the first recordings of its voice. Given that virtually all that is known of H. kaempferi are the scant details published by Collar et al. (1992) and Ridgely and Tudor (1994), 
we take the opportunity to provide new information on its conservation and ecology, and present the first field description. Furthermore, we present brief information on other threatened bird species recorded during our visits to Salto do Piraí, in order to support calls for the effective conservation of this biologically rich area (Collar et al. 1992).

\section{Records}

M.P., following two days of searching for H. kaempferi around the type-locality, watched a single individual for 10 minutes on 20 July 1991, C. $1.5 \mathrm{~km}$ downstream of the power station, at Salto do Piraí $\left(26^{\circ} 18^{\prime} \mathrm{S} 48^{\circ} 50^{\prime} \mathrm{W}\right)$.

Subsequent observations by the authors, and John Wall, have all been made within $80 \mathrm{~m}$ of the Rio Piraí, $c .500 \mathrm{~m}$ downstream of the gates to the hydroelectric plant. J.A.T. watched one individual in this area on 3-4 October 1995. On 7 February 1997, in the early morning, G.M.K. together with David Beadle, Rod McCann and Robert Williams found one in the same area in which J.A.T. had made his observations. G.M.K. returned to this area on 28-29 October 1998, together with a small group and, in the early morning of the second day, found a pair nestbuilding just a few metres upslope of the 1997 observation. J.M.B. recorded two different individuals on 8-11 April 1997 within 150 m of the February observation. On 20 April 1997, in precisely the same area as the 1995 observations, L.N.N. briefly observed a single individual at $15 \mathrm{~h} 30$ for approximately 30 seconds. Thirty minutes later, what was presumably the same bird, reappeared in the same area for $c$. 10 seconds. On 7 September 1997, J.W. briefly observed $H$. kaempferi in this area, very close to the Rio Piraí.

\section{New locality}

On 21 April 1998, L.N.N. recorded a lone individual at the Reserva Particular do Património Natural de Ponta Velha, Itapoá, in northern Santa Catarina (c. $26^{\circ} \mathrm{o} 6^{\prime} \mathrm{S}$ $48^{\circ} 4 \mathrm{o}^{\prime} \mathrm{W}$ ). It was located at 11 hoo, c. $1.5 \mathrm{~m}$ above the ground at the edge of a trail through primary lowland evergreen forest. It was very tame and moved rapidly from branch to branch, in the same manner as most Hemitriccus, with short noisy flights. A pair was observed in this area, for 1.5 hours, on 15 July 2000 (J.M.B., L.N.N.); next day another was found 1-2 km away.

\section{Habitat and behaviour}

All our observations were made in low-lying areas ( $150 \mathrm{~m}$ ) at shrubby forest edges, well-shaded secondary growth (with Cecropia sp. predominant) and sections of fairly low open woodland with many heliconias and dense ground flora. The canopy was $12-15 \mathrm{~m}$ at its highest (epiphytes abundant on the taller trees), but often under $10 \mathrm{~m}$, tree girths were fairly small (broadest $\mathrm{dbh} 30-40 \mathrm{~cm}$ ). Although large areas of tall canopy, mature evergreen forest are present at the site, and considerable time was spent in such habitat, H. kaempferi was not seen there. All, except the April 1998 observation (see "New locality"), were made close to river courses. On two occasions, a pair was seen crossing a dirt road, 2.5 
$\mathrm{m}$ wide, on one occasion entering a rather open garden with scattered low trees, close to a regular territory of the species.

Birds fed within the sparse foliage of the outer canopy and midstoreys of medium-sized trees, usually at $1-3 \mathrm{~m}$. They were quite active, in a manner typical of the other members of the genus (e.g. H. margaritaceiventer). Members of a pair foraged within $3 \mathrm{~m}$ of one another. M.P. noted an individual hover-gleaning in the subcanopy of a tree, at c. $6 \mathrm{~m}$, although it subsequently descended to $c .2 \mathrm{~m}$, where it loosely associated with a Golden-crowned Warbler Basileuterus culcivorus. Other feeding observations have involved one seen beating a green caterpillar against a branch, prior to consumption, and regular short $(<50 \mathrm{~cm})$ sallies to fly-catch within neighbouring vegetation. $H$. kaempferi is usually relatively conspicuous, even within forest, regularly perching on exposed branches or in the open, within hanging vines.

We have not observed the species to join mixed-species feeding flocks, but have consistently found the species within the same small area, over the course of several years, suggesting that it may have well-defined permanent territories. We have observed the same phenomenon in $H$. furcatus and H. orbitatum.

During the April 1997 and July 2000 observations, birds did not usually react very strongly to playback, at most approaching cautiously but keeping within the forest.

\section{Breeding biology}

No information has previously been recorded concerning the nesting ecology of the species. On 29 October 1998, while watching a pair of H. kaempferi, Travis McClendon draw G.M.K.'s attention to a previously unseen nest. It soon became apparent that the pair was actively nest-building, both members visiting the structure at regular intervals (approximately one visit every $2-5$ minutes) to add new items.

The nest was wrapped around a horizontal branch c. $6 \mathrm{~m}$ above the ground and was moderately well concealed by nearby leaves. It was $c .45 \mathrm{~cm}$ in overall length and situated within $15 \mathrm{~cm}$ of the main trunk of a narrow-trunked tree $(c$. $18 \mathrm{~m}$ tall with a dbh of $c$. $10 \mathrm{~cm}$ ). It was principally constructed of live mosses (c. 70\%) up to $8 \mathrm{~cm}$ long with most of the remainder being grasses and dead leaves (up to $c .2 \mathrm{~cm}$ long and $1 \mathrm{~cm}$ wide) and appeared likely to be an elongated cup-shape when completed. It was not possible to obtain additional measurements, e.g. the diameter of the cup. The nest was located 2-3 $\mathrm{m}$ inside primary forest at an altitude of $250 \mathrm{~m}$. Most surrounding trees were of similar height and structure. The forest in this vicinity is on relatively level ground (slope angle less than $5^{\circ}$ ) and the understorey moderately dense, but usually less than $25 \mathrm{~cm}$ in height.

\section{Vocalizations}

The usual vocalization consisted of a short series, often of four notes in two pairs or three more regularly spaced notes, which although variable in length, was always delivered at the same, rather even, pace. A single note sometimes preceded the main call. Each call was high-pitched, nasal, strident and raspy "kuít- 
kuit" or "kwit-kwit", sometimes given as "kwit kwit-kwit kwit-kwit-kwit-kwit", not dissimilar to the "Hwik. . Hwik-Hwik. . .Hwik-Hwik-Hwik-Hwik" given by Hemitriccus orbitatus. Calling was heard throughout the day, but more frequently in the early morning. A typical series of calls is shown in Figure 1, consisting of rather spaced pairs of notes reaching just over $6 \mathrm{kHz}$. A series of $7-14$ notes, delivered at a continuous pace, is believed to represent the song. Relatively similar in quality to calls, but seemingly lower pitched (the main component reaching $5 \mathrm{kHz} ; n=2$ ). Figure 2 shows one such series of 10 notes.

\section{Plumage description}

The only description available in the literature for this species is that included by Ridgely and Tudor (1994) and we therefore take this opportunity to present a more detailed plumage description. Head and face vary from pale brown tinged rufous to more brownish-olive, apparently dependent on lighting conditions, or perhaps due to the relative freshness of the plumage. The eye-ring is usually relatively weak, but appears more pronounced and whiter, and therefore a little reminiscent of $H$. orbitatus in some individuals (e.g. one of the nestbuilding pair observed in late October 1998) and also varies in prominence according to the angle of the bird's head relative to the observer. There is small greyish-buff or dull rust (M.P.) loral spot, which is less noticeable in direct or bright sunlight, but is highly noticeable in even light or in shade. A slight dusky smudge is sometimes present at the rear of the ear coverts (J.T.). The rest of the upperparts, including tail, are dull olive-green (considered brighter olive by M.P.). The throat is pale yellow, usually tinged with buff but occasionally duller, also depending on the light conditions; notably the breast is washed greenisholive, while the rest of the underparts are pale greenish-yellow, grading to pale yellow on the vent and whitish undertail-coverts. The wings are dark, with the secondaries fringed greenish-yellow, forming a slight wing-panel, and extremely broad and bold yellowish-cream fringes to the tertials. The two concealed wing bars are yellowish-buff in coloration. The outer pair of rectrices are slightly elongated and curve outwards, producing a slightly forked appearance, with the outer webs yellowish-cream and a dark subterminal band, although the shape may be variable. This pattern (and head coloration) is similar to $H$. furcatus, and may suggest a closer relationship between the two than heretofore realised. Indeed, the larger $H$. mirandae, with which it is usually presumed to form a superspecies, appears more closely related, on morphological characters, to the H. diops and H. orbitatum group.

The underwing-coverts are pale greenish-yellow. Bare parts: dark grey tarsi, blackish bill with an extensive pale basal two-thirds to the lower mandible, and a brown or warm fawn-brown iris. It is worth noting that $H$. orbitatus has been observed at both Salto do Piraí and nearby Joinville and could potentially cause confusion. It is, however, easily separated by its well-defined and conspicuous white eye-ring and slightly different call.

\section{Ornithological importance of Salto do Piraí}

Wege and Long (1995) note the occurrence of four additional species of globally threatened birds at the type-locality of $H$. kaempferi, making it potentially the 


\begin{tabular}{|c|c|c|c|c|c|c|}
\hline \multicolumn{7}{|c|}{ urameters } \\
\hline Window: & Hamming & FFT (Hz): & 512 & Frame (\%): & 100 & Overlap (\%): 50 \\
\hline \multicolumn{7}{|c|}{ Recording data } \\
\hline \multicolumn{2}{|l|}{ NSA ref. no: } & \multicolumn{3}{|l|}{ Date: } & \multicolumn{2}{|l|}{ Sound: } \\
\hline Species name: & He. kaempferi & Location: & $\mathrm{Bra}$ & & Recordist: & $\begin{array}{l}\text { J. Mazar } \\
\text { Barnett }\end{array}$ \\
\hline
\end{tabular}

$\uparrow \quad$ frequency (kiloHertz)

$\rightarrow \quad$ time (seconds)

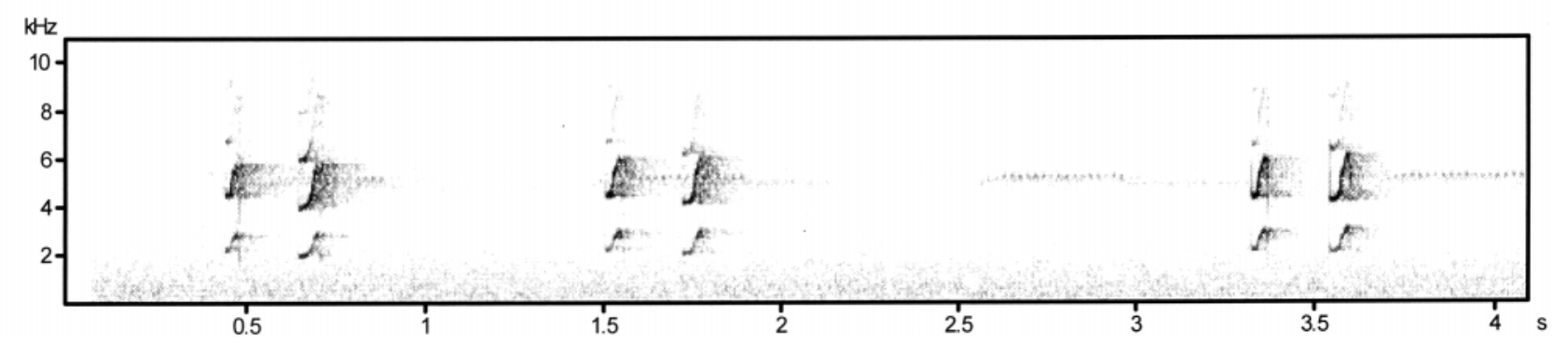

Figure 1. Sonogram of spaced calls of Hemitriccus kaempferi (Brazil: Salto do Piraí; J. Mazar Barnett recording). Prepared with Avisoft programme at the British Library National Sound Archive. 


\begin{tabular}{|c|c|c|c|c|c|c|}
\hline \multicolumn{7}{|c|}{ Analysis parameters } \\
\hline Window: & Hamming & FFT $(\mathrm{Hz}):$ & 512 & Frame (\%): & 100 & Overlap (\%): \\
\hline \multicolumn{7}{|c|}{ Recording data } \\
\hline NSA ref. no: & & Date: & & & Sound: & \\
\hline Species name: & He. kaempferi & Location: & & & Recordist: & $\begin{array}{l}\text { J. Mazar } \\
\text { Barnett }\end{array}$ \\
\hline
\end{tabular}
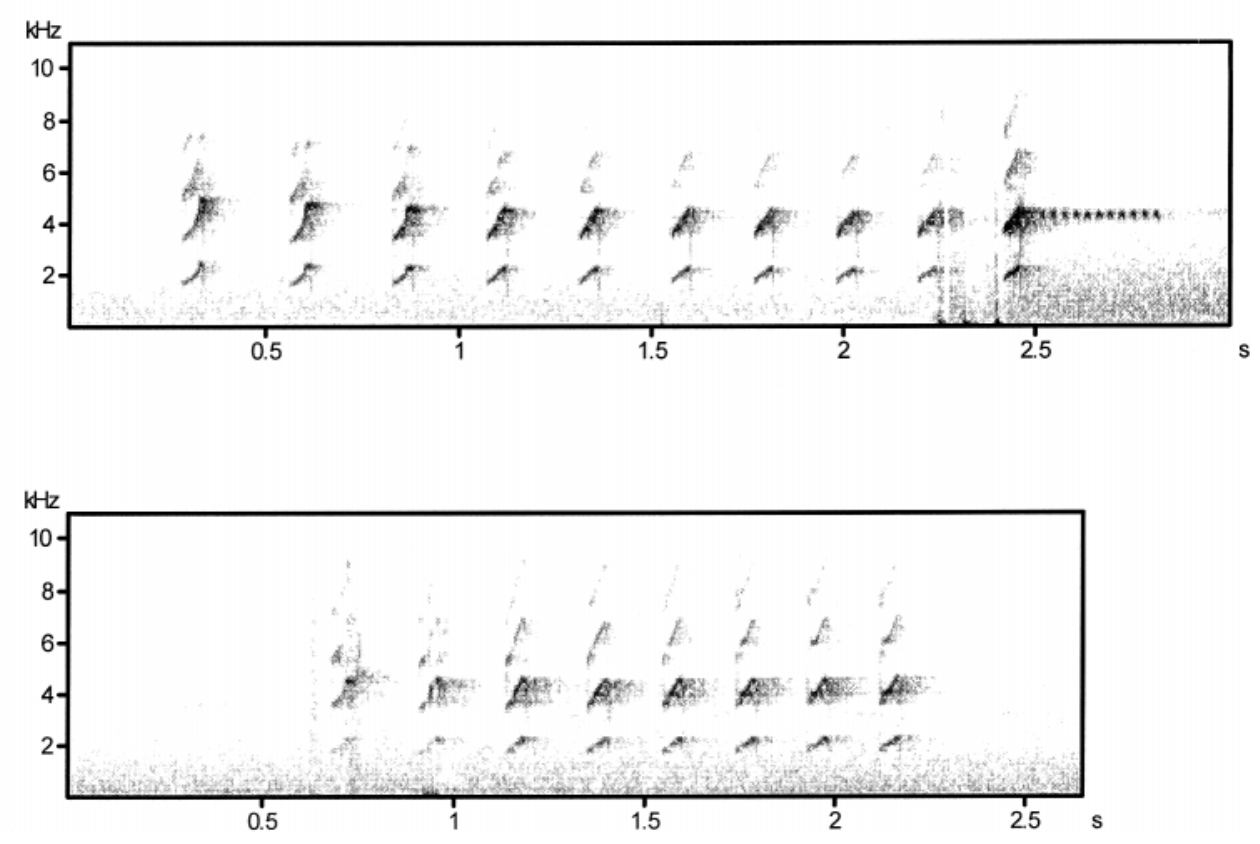

Figure 2. Presumed song of Hemitriccus kaempferi (Brazil: Salto do Piraí; J. Mazar Barnett recording). Note the trill commencing at 2.5 seconds is a frog. Prepared with Avisoft programme at the British Library National Sound Archive. 
most important site in the state for the conservation of threatened birds, namely White-necked Hawk Leucopternis lacernulata, São Paulo Tyrannulet Phylloscartes paulistus, Russet-winged Spadebill Platyrinchus leucoryphus and Pampas Meadlowlark Sturnella defilippii. Of these, Leucopternis lacernulata has been recorded twice (in July 1991 and April 1997), Platyrinchus leucoryphus and Sturnella defilippii have been recorded on just single occasions. The group of $35 \mathrm{~S}$. defilippii, noted in fields between Vila Nova and Salto do Piraí, in July 1991 (M.P.) appears to be the only state record (Rosário 1996). Phylloscartes paulistus has been recorded five times, in June 1929, July 1991, March 1994, October 1995 and October 1998 (Wege and Long 1995, Rosário 1996, Naka et al. in press) and is probably not uncommon in the area. In addition, Machado (1996) recorded Blue-bellied Parrot Triclaria malachitacea within the reserve.

Our fieldwork in the area has revealed the presence of other species of conservation concern. The globally threatened Salvadori's Myrmotherula minor (two on 3 October 1995) and Unicolored Antwrens M. unicolor (two on 3 October 1995, four on 4 October 1995, three on 9 April 1997 and one on 29 October 1998) are both present at the locality (Naka et al. in press).

In addition, L.N.N. recorded the globally threatened Helmeted Woodpecker Dryocopus galeatus at Reserva Particular do Patrimonio Natural de Ponta Velha, Itapoá, on 15 October 1998 (two birds) (Naka et al. in press). Given the brief nature of our fieldwork in both areas, further discoveries are likely.

\section{Conservation}

Kaempfer's Tody-tyrant is protected by Brazilian law (Bernardes et al. 1990, Paiva 1999), having been considered endangered by Collar et al. (1994) and included within the Brazilian Red Data list (Paiva 1999). Previously, Collar et al. (1992) had considered the species as having an Indeterminate threat status, i.e. a taxon known to be either Endangered, Vulnerable or Rare, but for which so little information is available it is impossible to designate more accurately the most appropriate threat category. Ridgely and Tudor (1994) and Collar et al. (1992) suggest that the species is partially protected by the Reserva Ecológica do Bracinho, Salto do Piraí, but no records are known from within this reserve, despite extensive mist-netting work there (Machado 1996), and specific searches during three visits by M.A. Da-Ré (pers. comm.) in 1987. The reserve principally encompasses lower montane, montane and uppermontane evergreen forest on steep slopes and as such there appears to be no suitable habitat for Kaempfer's Todytyrant. The lowland evergreen forests in the area - presumably the original habitat of the species - have virtually all been removed or, at best, highly modified by man's activities. As the species seems restricted to the flatter bottom of the small Piraí valley, most habitat at the site is not suitable. The area of secondary forest in the base of the valley is diminishing in extent to make way for housing, pasture and plantations of banana and palmito. While these habitats are unsuitable for the species, it can persist in second growth and edge, even being recorded in nearby gardens at Salto do Piraí, offering some hope for its survival. The possibility of annexing valley bottom secondary growth to the Reserva Ecológica do Bracinho should be investigated. All our visits to the area were of short duration and concentrated on the access road to the power station. However, the 
rest of the surrounding lowlands, although heavily converted, could potentially hold small numbers of the species and these should be surveyed as soon as possible. A low forested hillside on the outskirts of Joinville was visited in October 1995, but only H. orbitatus was found. Further destruction of remnant lowland evergreen forest fragments in the region should be minimized.

The additional locality for the species, discovered by L.N.N. - Reserva Particular do Patrimonio Natural de Ponta Velha, Itapoá - was created to protect one of the last remnants of lowland evergreen forest in Santa Catarina. The fact that Kaempfer's Tody-tyrant was located here permits hope that this rare and localized endemic may be protected within this area, although it also raises concerns for the future of the species, as lowland evergreen forest must be considered the most endangered habitat in Santa Catarina. The recognition of Reserva Ponta Velha as a new Key Area and surveys to estimate the extent to which this reserve protects a population of the species are also essential, as this is the only locality where the species is actually protected.

The reserve is very close to the border with Paraná and it is highly likely that $H$. kaempferi will be found in adjacent areas of similar habitat. However, neighbouring lowland areas are heavily disturbed, mostly being converted to banana and rice plantations. Thus, future field work should probably focus on northern Santa Catarina, around the Reserva Particular do Patrimonio Natural de Ponta Velha, where some significant tracts of lowland evergreen forest persist. These areas are also critically threatened, as Itapoá is swiftly developing as a beach resort for wealthy Brazilians and the demand for virgin land is constantly increasing.

The other historical locality where the species is known, Brusque (Teixeira et al. 1991), has not been visited subsequently. It would appear opportune to check the state of the habitat at this locality since, as noted above, the Kaempfer's Tody-tyrant survives in degraded areas.

We recommend the initiation of more concentrated ornithological sampling at these and other suitable sites in northern Santa Catarina and southern Paraná. Our fieldwork has been based solely on casual observations, rather than thorough surveys of the two areas. It is essential to initiate regular surveys in and around these localities, as well as at Brusque and adjacent areas of Paraná. Despite our data, still virtually nothing is known of the species in life, and future conservation initiatives would benefit from fieldwork designed to estimate approximate numbers and areas of occurrence, as well as to identify specific habitat preferences, in order to construct management plans that will protect the species's habitat. In light of the near total destruction of lowland forest, regrowth should be encouraged on properties adjacent to foothill forest.

\section{Acknowledgements}

The following shared some of our observations: David Beadle, Ken Cole, Mark Elwonger, Mike Flieg, Rod McCann, Travis McClendon, Howie Nielsen, Don Rathbun and Robert Williams. We also thank the staff of the CELESC station and operators of the power plant for granting permission and their assistance in visiting the area. John Wall generously shared and permitted us to publish his observations. Richard Ranft prepared the sonograms. 


\section{References}

Bernardes, A. T., Machado, A. B. M. and Rylands, A. B. (1990) Fauna Brasileira Ameaçada de Extinção. Belo Horizonte: Fundação Biodiversitas para a Conservação da Diversidade Biológica.

Collar, N. J., Crosby, M. J. and Stattersfield, A. J. (1994) Birds to watch 2: the world list of threatened birds. Cambridge, U.K.: International Council for Bird Preservation.

Collar, N. J., Gonzaga, L. P., Krabbe, N., Madroño Nieto, L. G., Naranjo, L. G., Parker, T. A. and Wege D. C. (1992) Threatened birds of the Americas: the ICBP/IUCN Red Data Book. Cambridge, U.K.: International Council for Bird Preservation.

Fitzpatrick, J. W. (1976) Systematics and biogeography of the Tyrannid genus Todirostrum and related genera (Aves). Bull. Mus. Comp. Zool. 147: 435-463.

Machado, D. A. (1996) Estudo de populações de aves silvestres da região do Salto do Piraí e uma proposta de conservação para a Estação Ecológica do Bracinho, Joinville - SC. Dissertação de Mestrado - ESALQ/USP.

Naka, L. N., Mazar Barnett, J., Kirwan, G. M., Tobias, J. A. and Azeredo, M. A. G. de (in press) New and noteworthy bird records from Santa Catarina state, Brazil. Bull. Brit. Orn. Club.

Naumburg, E. M. B. (1939) Studies of birds from eastern Brazil and Paraguay, based on a collection made by Emil Kaempfer. Bull. Am. Mus. Nat. Hist. 76: 231-276.

Paiva, M. P. (1999) Conservação da fauna Brasileira. Rio de Janeiro: Ed. Interciência.

Ridgely, R. S. and Tudor, G. (1994) The birds of South America, II. The suboscine passerines. Oxford, U.K.: Oxford University Press.

Rosário, L. A. do (1996) As aves em Santa Catarina. Distribuçáo geográfica e meio ambiente. Florianópolis: Fundação do Meio Ambiente.

Stattersfield, A. J., Crosby, M. J., Long, A. J. and Wege, D. C. (1998) Endemic Bird Areas of the world: priorities for biodiversity conservation. Cambridge, U.K.: BirdLife International (BirdLife Conserv. Series 7).

Teixeira, D. M., Nacinovic, J. B. and Schloemp, I. M. (1991) Notas sobre alguns passeriformes brasileiros pouco conhecidos. Ararajuba 2: 97-100.

Wege, D. C. and Long, A. J. (1995) Key Areas for threatened birds in the Neotropics. Cambridge, U.K.: BirdLife International (BirdLife Conserv. Series 5).

JUAN MAZAR BARNETT

Av. Forest 1531 IB, (1430) Buenos Aires, Argentina.

GUY M. KIRWAN

74 Waddington Street, Norwich NR2 4JS, U.K.

MARK PEARMAN

San Blas 3985 37, (1407) Buenos Aires, Argentina.

LUCIANO NICOLÁS NAKA

Haroldo Sores Glavan 4280, Cacupé (88050-00o) Florianópolis, Santa Catarina, Brazil.

JOE A. TOBIAS

c/o BirdLife International, Wellbrook Court, Girton Road, Cambridge CB3 oNA, U.K. 
